\title{
The role of public policies in reducing smoking prevalence and deaths: the Argentina Tobacco Policy Simulation Model
}

\author{
Daniel Ferrante, ${ }^{1}$ David Levy, ${ }^{2}$ Armando Peruga, ${ }^{3}$ \\ Christine Compton, ${ }^{2}$ and Eduardo Romano ${ }^{2}$
}

Suggested citation Ferrante D, Levy D, Peruga A, Compton C, Romano E. The role of public policies in reducing smoking prevalence and deaths: the Argentina Tobacco Policy Simulation Model. Rev Panam Salud Pública. 2007;21(1):37-49.

ABSTRACT Objectives. To compare tobacco control policies independently and as a package through a simulation model to project smoking prevalence and associated future premature mortality in Argentina beginning in 2001.

Methods. A simulation model of tobacco control policies known as SimSmoke was modified using data for Argentina on population, fertility and mortality, smoking prevalence, and to bacco control policies in effect between 2001 and 2004. We used the Argentina Tobacco Policy Simulation model (ATPSM) to consider the effect on smoking prevalence of changes in taxes and prices, clean air laws, media campaigns, cessation programs, and youth access policies on smoking initiation and cessation rates. Smoking prevalence and relative risks of smoking were used to estimate smoking-attributable mortality. The ATPSM was used to project smoking prevalence and smoking-attributable deaths during the period 2001-2034.

Results. The largest reductions in smoking prevalence and premature mortality were pre dicted for a comprehensive tobacco control policy package, but relative reductions of as much as $30 \%$ were also predicted for large tax increases. Adding a media campaign along with pro grams to publicize and enforce clean air laws, advertising bans, and youth access laws would further reduce smoking rates by up to 45\% by the year 2034, and would save almost 16000 lives per year.

Conclusions. Tobacco control policies can substantially reduce smoking rates, which can save many lives. Without such policies, deaths from smoking, and associated medical costs, will increase. The ATPSM is expected to provide guidance in filling the most important in formation gaps pertinent to both modeling and policy-making in Argentina, e.g., the lack of data on initiation and cessation rates, and the need for studies on the impact of policies. Sim ilar models might be developed for other Latin American countries.

Key words Computer simulation, health policy, smoking, tobacco, Argentina.

Ministerio de Salud, Programa VIGI+A, Buenos Aires, Argentina.

2 Pacific Institute for Research and Evaluation, Calverton, Maryland, United States of America. Send correspondence and reprint requests to: David T. Levy, Pacific Institute for Research and
Evaluation, 11720 Beltsville Drive, Suite 900, Calverton 20705-3102, Maryland, United States of America; e-mail: Levy@pire.org

3 Tobacco Control, Pan American Health Organization, Washington, D.C., United States of America.
Smoking is the single most preventable cause of premature mortality and of increases in the risk of lung cancer, emphysema, heart disease, stroke, and other diseases $(1,2)$. Globally, it is 
estimated that 5 million deaths each year are attributable to smoking (3), with trends driving a rise to 10 million deaths per year by the 2030s (4).

Evidence indicates that higher cigarette taxes, clean air laws, media campaigns, banning the promotion of tobacco products, and warning labels can appreciably reduce smoking (5-7). These policies are part of the Framework Convention for Tobacco Control (FCTC) of the World Health Organization. They not only reduce smoking initiation, but also encourage cessation, which reduces smoking-attributable deaths $(2,8)$.

Most empirical analyses of tobacco control policies have been conducted for the United States of America, Australia, and European countries. Less is known about the impact of policies in other countries. Nevertheless, it is important for other countries to develop comprehensive programs to reduce smoking. Argentina has signed the FCTC (9), and will likely ratify it, but tobacco control efforts are at an early stage.

This paper describes a preliminary planning model for Argentina, which we call the Argentina Tobacco Policy Simulation Model (ATPSM). The model is patterned after SimSmoke, a tobacco control policy model developed for the United States $(10,11)$. On the basis of data from Argentina on population, birth rates, death rates, and smoking rates, ATPSM predicts future smoking rates and deaths attributable to smoking in total as well as by age and gender. The model also evaluates the effect of individual tobacco control policies on smoking rates and smoking-attributable deaths. In addition, the model helps to identify the data needed for the effective surveillance of smoking and health consequences, and the types of policy evaluations needed.

\section{MATERIAL AND METHODS}

Like the model developed in the United States, the ATPSM includes a population model, a smoking model, a smoking-attributable death model, and policy modules. The United States model is described in detail in previous articles (10-13), and on the Web at https: / / cisnet.flexkb.net/mp / pub / cisnet_lung_pire_profile.pdf. The year 2001 was chosen as the baseline year because a large-scale survey collected information on smoking rates in Argentina that year. The data sources are described in Table 1.

\section{Population model}

The population model was based on population identified by age and gender. For the baseline year 2001, data on the total population by age and gender were obtained from the 2001 census in Argentina. Data on fertility rates by age and mortality rates by age and gender were obtained from the Department of Statistics of the Ministry of Health, and include all deaths and births for 2001 .

\section{Smoking model}

The baseline year population was divided into the number of smokers, never smokers, and previous smokers by age and gender. Within the smoking model some individuals evolved from never smokers to smokers through smoking initiation. Individuals were classified as never smokers from birth until they initiated smoking or died. A portion of smokers evolved to ex-smoker status through cessation, but some of these individuals may return to smoking through relapse. (The extent of relapse depends on the number of years since quitting.)

Data on smoking were obtained from two sources. In the 2001 SIEMPRO study Encuesta de Condiciones de Vida, participants were 15 years old or more from cities with more than 5000 inhabitants $(96 \%$ of the urban population, $83 \%$ of total population). The survey included 26000 households in the sample frame, with an $80 \%$ response rate; in all, 22910 persons were interviewed. The survey included extensive information about household characteristics, and a separate section on smoking. The interview asked whether the individual had actually smoked during the previous day, and, if not, whether they had smoked in the past. Data were also obtained from the 1999 SEDRONAR survey Encuesta Epidemiológica sobre Prevalencia de Con sumo de Sustancias Psicoactivas en Ar gentina, which interviewed 2699 individuals aged 12 to 64 years, with a response rate of $>80 \%$. Individuals were asked whether they had ever smoked. Those who had were asked whether they had smoked in the previous 30 days; those that hadn't were asked whether they had quit in the previous two years.

For the simulation model, it was important to capture established smokers, often defined as those who have smoked more than 100 cigarettes in their lifetime. The 1999 data indicated smoking rates about $10 \%$ higher than the 2001 data. However, the 1999 data may have overstated smoking by including anyone who had smoked in the previous 30 days, whereas the 2001 data may have understated smoking rates due to the exclusion of some-day smokers and due to temporarily lower rates from the economic downturn that survey year. To remedy these problems, we used the 2001 data to distinguish smoking rates by age, because this survey was based on a substantially larger sample and included persons above age 64 . We then used the 1999 data to scale the 2001 data upwards to reflect the omission of someday smokers and the economic downturn. For those aged 35 years and older, we corrected the 2001 smoking rates upwards by adding $75 \%$ of the average difference between smoking rates in 1999 and 2001. For those below age 35 years, we added $50 \%$ of the difference between the 1999 and 2001 rates, since non-established smokers were more likely to be captured by the last-30-days measure for these ages in the 2001 survey.

Ex-smokers included anyone who had ever smoked, but no longer smoked. We used data from the 1999 national survey to examine the percent of ex-smokers who had quit in the previous year and between 1 and 2 years 
TABLE 1. Measures and data sources used for the Argentina Tobacco Policy Simulation Model

\begin{tabular}{|c|c|c|}
\hline Variable & Source & Description \\
\hline \multicolumn{3}{|l|}{ Population model } \\
\hline Current population & $\begin{array}{l}\text { www.indec.mecon.gov.ar/Población/ Composición de la Población/ } \\
\text { Población por sexo según edad en años simples. Año } 2001\end{array}$ & $\begin{array}{l}\text { Population with breakdowns by age and gender } \\
\text { from the } 2001 \text { census (most recent available) }\end{array}$ \\
\hline Fertility rates & $\begin{array}{l}\text { Ministerio de Salud y Ambiente de la Nación. Secretaría de Políticas, } \\
\text { Regulación y Relaciones Sanitarias, Subsecretaría de Relaciones } \\
\text { Sanitarias e Investigación en Salud, Dirección de Estadísticas e } \\
\text { Información y Salud. } \\
\text { Estadisticas Vitales-Informacion Basica Año 2001, diciembre de } 2002\end{array}$ & $\begin{array}{l}\text { Births per } 1000 \text { women by age. Vital statistics } \\
\text { from Ministry of Health for } 2002\end{array}$ \\
\hline \multicolumn{3}{|l|}{ Smoking rate model } \\
\hline $\begin{array}{l}\text { Baseline smoking rates } \\
\text { for current smokers and } \\
\text { ex-smokers }\end{array}$ & $\begin{array}{l}\text { Secretaría de Programación para la Prevención de la Drogadicción y } \\
\text { Lucha contra el Narcotráfico (SEDRONAR) } \\
\text { Encuesta Epidemiológica sobre Prevalencia de Sustancias } \\
\text { Psicoactivas en Argentina, } 1999 \\
\text { Sistema de Evaluación y Monitoreo de Programas Sociales } \\
\text { (SIEMPRO), Presidencia de la Nación } \\
\text { Mabel Ariño, Beatriz Toutoundjian. Consumo de tabaco en la } \\
\text { Argentina, marzo } 2003 \text { (Encuesta de Condiciones de Vida 2001) } \\
\text { (National Survey, 2001) }\end{array}$ & $\begin{array}{l}\text { Number of current smokers (at least } 100+ \\
\text { cigarettes lifetime) by gender and age. National } \\
\text { survey ( } n=2699,12-64 \text { years) performed in } \\
1999\end{array}$ \\
\hline Initiation rates & Same as above for smoking rates & $\begin{array}{l}\text { Inferred from current smoking rates in those } \\
\text { aged } 10-24 \text { years }\end{array}$ \\
\hline $\begin{array}{l}\text { Baseline rates for } \\
\text { ex-smokers }\end{array}$ & Same as above for smoking rates & $\begin{array}{l}\text { At least } 100+\text { cigarettes lifetime and not currently } \\
\text { smoking, by gender and age. Asked time elapsed } \\
\text { since quitting for }<1 \text { year, } 1-2 \text { years, } 2+\text { years; } \\
\text { used United States breakdowns for } 3+\text { years }\end{array}$ \\
\hline First year cessation & Same as above for smoking rates & $\begin{array}{l}\text { Population indicator of annual cessation rates in } \\
\text { the previous year not available, so we estimated } \\
<1 \text { year ex-smokers as a percent of smokers } \\
\text { plus }<1 \text { year ex-smokers }\end{array}$ \\
\hline Relapse rates & Data from the United States $(14,15,16)$ & $\begin{array}{l}\text { Not available; data from the United States were } \\
\text { used }\end{array}$ \\
\hline $\begin{array}{l}\text { Relative death risks } \\
\text { of smokers and } \\
\text { ex-smokers }\end{array}$ & Various sources from the United States cited in the CPS-II study (20) & $\begin{array}{l}\text { No large-scale studies available, but some } \\
\text { supporting evidence from smaller case studies } \\
\text { for Argentina }\end{array}$ \\
\hline & $\begin{array}{l}\text { Tobacco price: Ministerio de la Producción, Secretaría de Agricultura, } \\
\text { Ganadería, Pesca y Alimentos, Subsecretaría de Economía } \\
\text { Agropecuaria; Fondo Especial del Tabaco. Anuario estadístico, } \\
\text { Campañas 2001-2002-2003 y Ministerio de Economía }\end{array}$ & \\
\hline & $\begin{array}{l}\text { Tobacco tax: Ministerio de la Producción, Secretaría de Agricultura, } \\
\text { Ganadería, Pesca y Alimentos, Subsecretaría de Economía } \\
\text { Agropecuaria. Corradini E et al. Caracterización del Sector Productor } \\
\text { Tabacalero en la República Argentina, } 2004\end{array}$ & \\
\hline & $\begin{array}{l}\text { Perazzo D. Impuestos al tabaco: efectos sobre el precio y el } \\
\text { consumo y situación en la República Argentina. www.uata.org.ar }\end{array}$ & \\
\hline Clean air laws & $\begin{array}{l}\text { Tobacco Control Country Profiles database and information provided } \\
\text { by tobacco control staff in Argentina }\end{array}$ & $\begin{array}{l}\text { Different types of laws currently in effect and } \\
\text { their stringency as distinguished by region }\end{array}$ \\
\hline $\begin{array}{l}\text { Media and other } \\
\text { educational campaigns }\end{array}$ & $\begin{array}{l}\text { Tobacco Control Country Profiles database and information provided } \\
\text { by tobacco control staff in Argentina }\end{array}$ & Indication of current level of media campaigns \\
\hline $\begin{array}{l}\text { Advertising bans/Health } \\
\text { warnings }\end{array}$ & $\begin{array}{l}\text { Tobacco Control Country Profiles database and information provided } \\
\text { by tobacco control staff in Argentina }\end{array}$ & $\begin{array}{l}\text { Extent of advertising bans on tobacco manufac- } \\
\text { turers and required health warnings on labels }\end{array}$ \\
\hline Youth access & $\begin{array}{l}\text { Tobacco Control Country Profiles database and information provided } \\
\text { by tobacco control staff in Argentina }\end{array}$ & $\begin{array}{l}\text { Current policies regarding age limitations, enforce- } \\
\text { ment checks, penalties, community campaigns, } \\
\text { self-senvice and vending machine bans }\end{array}$ \\
\hline
\end{tabular}


earlier. We found that the overall exsmoker rates were similar for Argentina and the United States, and consequently used relative percentages within categories from United States data obtained from the 1993 Tobacco Use Supplement to the Current Population Survey (TUS-CPS) to distinguish the percent of ex-smokers by years since quitting in the $3+$ years categories. Smoking rates were calculated by 5 -year age groups for ages 22 years and above, and for each age from 15-21 years, to observe the patterns of increase in younger participants.

Because precise data on initiation and cessation rates were not available for those below age 22 years, and to ensure stability of the model, initiation rate at each age was measured as the difference between the smoking rate (from the Argentine prevalence data) at that age year and the rate at the previous age year. Because smoking rates began to level off at age 22 years in males and females, the ages of initiation in the ATPSM were considered until age 22 in both genders.

Cessation was tracked from age 22 years, since smoking before that age was less likely to have health implications for ex-smokers. With data from the 1999 SEDRONAR survey, 1-year cessation rates were initially calculated as reflecting persons who were smokers 1 year previously and were not smokers at the time of the survey, divided by those who were smokers 1 year previously (including those who had quit in the previous year). However, because of the way smoking was defined, the data provided an implausibly high percentage of ex-smokers in the last year. Instead, we used United States data from the TUS-CPS for the year 1993. Because relapse data were not available for Argentina, we used United States rates (1, 2, 14, 15).

Smoking-attributable deaths in the ATPSM were predicted using death rates, smoking prevalence rates, and the total mortality risks of smokers and ex-smokers relative to non-smokers (16). We first distinguish the death rates of never smokers, smokers, and ex-smokers, based on the standard attributable risk formulation, which takes into account relative risks and smoking prevalence. Relative risks were calculated for 10-year age groups, except for the lowest (age 35-49 years) and highest age groups (age 80 years and above). The number of smokers at each age was then multiplied by the difference between the death rate of smokers and the death rate of never smokers to calculate the excess deaths due to smoking. The same procedure was used for each ex-smoker group, and the results were summed over smoker and ex-smoker groups for all ages to obtain the number of smokingattributable deaths for a given year.

Earlier studies of smoking risks in Argentina were small case-control studies, and examined only heart disease (17, 18), lung cancer (19) and other selected cancers. Because estimates from these studies were consistent with studies done in the United States $(20,21)$, we used United States data to gauge relative risk. Data were obtained from the large-scale Cancer Prevention Study II and other studies done in the United States $(20,21)$. The ATPSM used a value of 2.1 for the relative risk of average total mortality from smoking, with variations across ages. For ex-smokers, relative risks declined at the rate observed in United States studies.

\section{Policy modules}

In the ATPSM, the greatest effect of policies on cessation appeared directly as a change in prevalence rate in the first year when a given policy was in effect. Each of the policies also continued to affect initiation and first-year cessation rates while in effect. The changes were calculated in percentage terms relative to the initial rates [(postpolicy rate - initial rate)/initial rate]. The predicted effects were based on thorough reviews of the literature and the advice of an expert panel, and the results have been published in refereed journals $(13,22-27)$. Because these estimates were primarily from the United States, Australia, and European countries, these estimates should be viewed as preliminary.
We modeled the effects of price interventions (taxes), clean indoor air laws, mass media policies, advertising bans/warning labels, and strategies to reduce youth access to cigarettes (Table 2). For each policy module, we considered policies in effect and studies or factors relevant to the effects of policies in Argentina. Information on policies in effect was from the Tobacco Control Country Profiles database (http: / / apps.nccd.cdc.gov/nations / index.asp), and Tobacco Control staff in Argentina (Table 1). Policies in effect in 2001 were used initially, and any changes in policy were tracked over the 2001-2004 period.

Earlier studies have estimated the effect of pricing and taxes on price elasticity, defined as the percent change in consumer demand for a product in response a $1 \%$ change in the price. Chaloupka et al. (28) found that more developed countries had price elasticities of -0.4 , which means that a $10 \%$ price rise causes the quantity of cigarettes demanded to fall by $4 \%$, compared to -0.8 in less developed countries. Using time-series data, other researchers (29) obtained a price elasticity of -0.3 for Argentina, similar to that in the United States.

Taking into account the overall price elasticity, the ATPSM further distinguished the price elasticity of demand for cigarettes (which reflected the average demand for the total population) by age group, and focused on the prevalence elasticity. Based on previous studies in the United States that analyzed different age groups and prevalence elasticity $(28,30)$, and in light of overall price elasticities for Argentina relative to the United States, we used an elasticity of -0.6 for individuals younger than 24 years, -0.35 for those aged 25 to 34 years, -0.2 for those aged 35 to 44 years, and -0.1 for those aged 45 years and above. We did not analyze gender differences or include income in the model, because previous studies yielded ambiguous results on the role of these variables (28).

In the ATPSM, cigarette use was directly related to the retail price relative to the prices of other goods, in accordance with economic theory. For the 
TABLE 2. Policy inputs for projections obtained with the Argentina Tobacco Policy Simulation Model

\begin{tabular}{|c|c|}
\hline Policy & Description \\
\hline \multicolumn{2}{|l|}{ Tax policy } \\
\hline Most recent price & $\begin{array}{l}\text { Actual prices, usually price per pack of most widely smoked } \\
\text { cigarettes or an average price (weighted by amount of major brands } \\
\text { smoked) }\end{array}$ \\
\hline Most recent tax rate & Actual tax rates (as a percent of price) \\
\hline \multicolumn{2}{|l|}{ Clean air policies } \\
\hline $\begin{array}{l}\text { Work site total ban, } \\
\text { well-enforced }\end{array}$ & $\begin{array}{l}\text { Ban in all indoor work sites in all areas, with strong public } \\
\text { acceptance and enforcement of laws }\end{array}$ \\
\hline $\begin{array}{l}\text { Work site total ban, } \\
\text { not well enforced }\end{array}$ & $\begin{array}{l}\text { Ban in all indoor work sites in all areas, with low public acceptance } \\
\text { and enforcement of laws }\end{array}$ \\
\hline Work site partial ban & Ban in all indoor work sites except in designated areas \\
\hline Restaurant total ban & Ban in all indoor restaurants in all areas \\
\hline Restaurant partial ban & Ban in all restaurants except in designated areas \\
\hline Other places bans & $\begin{array}{l}\text { Ban in three of four (government buildings, retail stores, public } \\
\text { transportation, and elevators) }\end{array}$ \\
\hline Enforcement & Government agency to actively enforce the laws \\
\hline Publicity & Media campaign to publicize the law \\
\hline \multicolumn{2}{|l|}{ Mass media campaigns } \\
\hline $\begin{array}{l}\text { Highly publicized media } \\
\text { campaign }\end{array}$ & $\begin{array}{l}\text { Campaign publicized heavily on TV (at least two months of the year) } \\
\text { and at least some other media, with a social marketing approach }\end{array}$ \\
\hline Other policies in place & $\begin{array}{l}\text { Other policies (at least two of the following), such as tax increases, } \\
\text { cessation programs, and clean air initiatives are also currently being } \\
\text { implemented. }\end{array}$ \\
\hline \multicolumn{2}{|l|}{ Advertising bans } \\
\hline $\begin{array}{l}\text { Comprehensive advertising } \\
\text { ban }\end{array}$ & $\begin{array}{l}\text { Ban on advertising in television, radio, print, billboard, in-store } \\
\text { displays, and sponsorships }\end{array}$ \\
\hline Enforcement & Government agency to actively enforce the laws \\
\hline Publicity & Media campaign to publicize the law \\
\hline Warning labels & Large, attention-getting, and explicit labels \\
\hline \multicolumn{2}{|l|}{ Youth access restrictions } \\
\hline $\begin{array}{l}\text { Strongly enforced and } \\
\text { publicized }\end{array}$ & $\begin{array}{l}\text { Compliance checks conducted four times per year per outlet; strong, } \\
\text { enforced penalties; publicity and heavy community participation }\end{array}$ \\
\hline Well enforced & $\begin{array}{l}\text { Compliance checks are conducted four times per year per outlet; } \\
\text { strong penalties; publicity and merchant training but little community } \\
\text { support }\end{array}$ \\
\hline Low enforcement & $\begin{array}{l}\text { Compliance checks conducted sporadically; weak penalties; little } \\
\text { merchant awareness or community participation }\end{array}$ \\
\hline
\end{tabular}

period 2001-2004, we used unpublished data on prices from the Ministry of Economy (Dirección Nacional de In vestigaciones y Análisis Fiscal, Subsecre taría de Ingresos Públicos, Ministerio de Economía) adjusted for inflation, to consider the effect of price. From 2004, we assumed that cigarette prices relative to inflation remained constant in the absence of tax changes. We assumed that prices increased by the amount of the tax, based on studies reported by Chaloupka and others (28).
Argentina imposed ad valorem taxes (based on the price of the product) rather than specific taxes (based on the number of units sold) on cigarettes. The tax was about $68 \%$ of the final retail price, which would imply a pre-tax price of $\operatorname{Arg} \$ 0.54$ and taxes of $\operatorname{Arg} \$ 1.21$. Using the pre-tax price for the most recent year, we predicted future total prices as the pre-tax price in 2004 divided by ( 1 - the future tax rate in terms of final price). We assume that the pre-tax price increases with the rate of inflation, so that its price relative to other prices (and the standard of living) stays constant.

The clean air policy module examined the effect of laws that restricted smoking in work sites, restaurants, and other public places. Compared to no clean air laws, the United States model (22) predicted a 10\% reduction in prevalence with complete bans, strong enforcement, and media publicity. Work site laws had the largest effect, yielding a $6 \%$ reduction, with restaurant laws yielding a 3\% effect, and laws covering other public places having a $1 \%$ effect. Work site bans without high compliance had twothirds the effect of a total ban with high compliance, and partial work site and restaurant bans had one-third the effect of total bans. Media publicity and enforcement yielded an added $0.5 \%$ effect each at work sites and restaurants.

The effects for the United States workforce took into account that only about $50 \%$ of adults, i.e., those who worked indoors (some did not work, and others worked outdoors). About 8\% of the Argentina workforce in 2001 was employed in agriculture (Censo Nacional 2001, INDEC), compared to about $2 \%$ in the United States, and the labor participation rate in Argentina was $57 \%$ compared to about $70 \%$ in the United States (Condición de actividad económica según sexo, Censo Nacional 2001, INDEC). In the absence of studies of clean air laws for Argentina, we estimated that work site laws in Argentina had $80 \%$ of the effect in the United States, and that bans on smoking at restaurants, schools, and other sites had the same effect.

Clean air laws in Argentina have stayed the same since 2001. National and provincial laws ban smoking on public transport and some other public facilities (e.g., hospitals), but are weak and often not enforced, and there are no restrictions on smoking in other important public areas such as shopping areas. In Buenos Aires, smoking in work sites is restricted to designated areas. There have been some attempts to enforce work site laws. We considered there to be partial 
bans (limited to work areas) for work sites, but no clean air laws for restaurants or other public areas. A restaurant ban came into effect in mid-2006 in Buenos Aires, and some provinces approved clean air laws in mid-2005, but enforcement is weak.

Media campaigns are generally used to educate the populace about the harms of smoking, but may also be used to mobilize support for tobacco control. The effectiveness of mass media campaigns depends on their scale, and the publicity (e.g., in the newspaper or on television) that other policies generate when they are in place (26). In the United States model, a large-scale mass media campaign directed at all smokers yielded a reduction in up to $7 \%$ in smoking rates in the entire population when combined with other policies, whereas a little-publicized campaign had $20 \%$ of the effect of a highly-publicized campaign (26). In Argentina, the ability of media campaigns to affect smokers may be greater than in the United States, due to the lower level of awareness about the dangers of smoking (31), but the ability to effectively reach smokers and the reinforcing effect of other policies may be less. We assumed the effects were the same in the ATPSM as in the United States model.

Before 2002 there was only one publicized national "Quit and Win" day, when those who quit smoking were eligible for a monetary prize through the lottery. Since 2002 there have been sporadic national campaigns on television. As in the United States model (32), we estimated that a comprehensive ban would lead to a $4 \%$ reduction in prevalence, a $2 \%$ increase in cessation rates, and a $6 \%$ reduction in initiation rates, whereas a partial ban would lead to a reduction of only $1 \%$ in prevalence and initiation rates. The larger effects on initiation rate were evidence that young people were particularly amenable to advertising. Vigilant monitoring and enforcement of a comprehensive ban added a $1 \%$ reduction to the effect of a comprehensive ban on prevalence and initiation rates. Currently, Argentina has a national ban on advertising in magazines and television programs aimed at a young audience, restrictions on sponsorship, and some local restrictions (e.g., billboards in Buenos Aires). In the model we characterized the advertising ban policy as a partial ban since 2001 .

Health warnings were considered to be effective only if they were large, attention-getting and explicit, and covered at least $30 \%$ of the total surface area of the package as indicated by the FCTC. Lower levels of health warnings have not been found to be effective. According to the parameters in the United States model (32), health warnings reduced the initiation and prevalence rates by $1 \%$ and increased the cessation rate by $2 \%$ (33-36). Current warnings on cigarette packages in Argentina are small and not bold or graphic, similar to that in the United States, indicating that such warnings are probably not effective.

Youth access policies are directed at young people who purchase tobacco. With a well-enforced (frequent enforcement checks and strong penalties) and highly publicized program, youth prevalence was reduced by $40 \%$ for 10-to-15-year-olds, and by $20 \%$ for 16-to-17-year-olds (23). Between 50\% and $60 \%$ of Argentine youth buy cigarettes in stores (37). These percentages are similar to those in the United States, so that the same parameters were used in the youth access module for the ATPSM.

Argentina currently has a ban on the purchase of tobacco by persons below age 18 years in all provinces. However, there is reportedly little enforcement. According to the 2000 Global Youth Tobacco Survey, more than $90 \%$ of young people who bought cigarettes in a store were not refused purchase because of their age. We therefore considered that there was no enforcement during the 2001-2004 period.

\section{The effect of enhancing tobacco control policies}

The population, smoking, and policy models were programmed with Excel software. We considered the effect of different policies on smoking and death rates from the year 2005 onward. We first assumed that policies remained constant after 2004, which we call the status quo scenario. Because additional policies were implemented in 2005, predictions were made relative to 2004 . We examined the effect of each policy individually by implementing the policy at a specific level for the year 2005 and holding that level constant in all future years. After examining policies individually, we then entered a combination of policies (at their strictest level, for those analyzed at different levels of intensity) to predict the impact of a comprehensive strategy. We compared the smoking and death rates predicted by the comprehensive strategy and the status quo scenario over a 30-year period from 2004 to 2033.

\section{RESULTS}

We present the estimated effects of tobacco control policies implemented in isolation and as a comprehensive tobacco control strategy. Estimates of smoking prevalence in the status quo scenario and different policy scenarios are shown in Tables 3a for males and $3 \mathrm{~b}$ for females. Smoking prevalence was measured as a percent of the adult population aged 18 years and above. The total number of projected deaths attributable to smoking is give for the different scenarios in Tables $4 \mathrm{a}$ for male and $4 \mathrm{~b}$ for females.

\section{Status quo scenario}

Smoking prevalence in adult males declined in absolute terms by $2.4 \%$ between 2001 and 2004, from 39.7\% to $37.3 \%$, for a relative reduction of $7.2 \%$. The ATPSM predicted an increase in the smoking rate to $39.8 \%$ between 2001 and 2002 due to a $17 \%$ reduction in the inflation-adjusted price of cigarettes (slightly offset by the addition of a media campaign). A reduction in the smoking rate from $39.0 \%$ in 2003 to $37.3 \%$ in 2004 was due to a $20 \%$ price increase from taxes. 
TABLE 3a. Smoking prevalence rates in males predicted for different years by the status quo model and under different scenarios of the Argentina Tobacco Policy Simulation Model ${ }^{\mathrm{a}}$

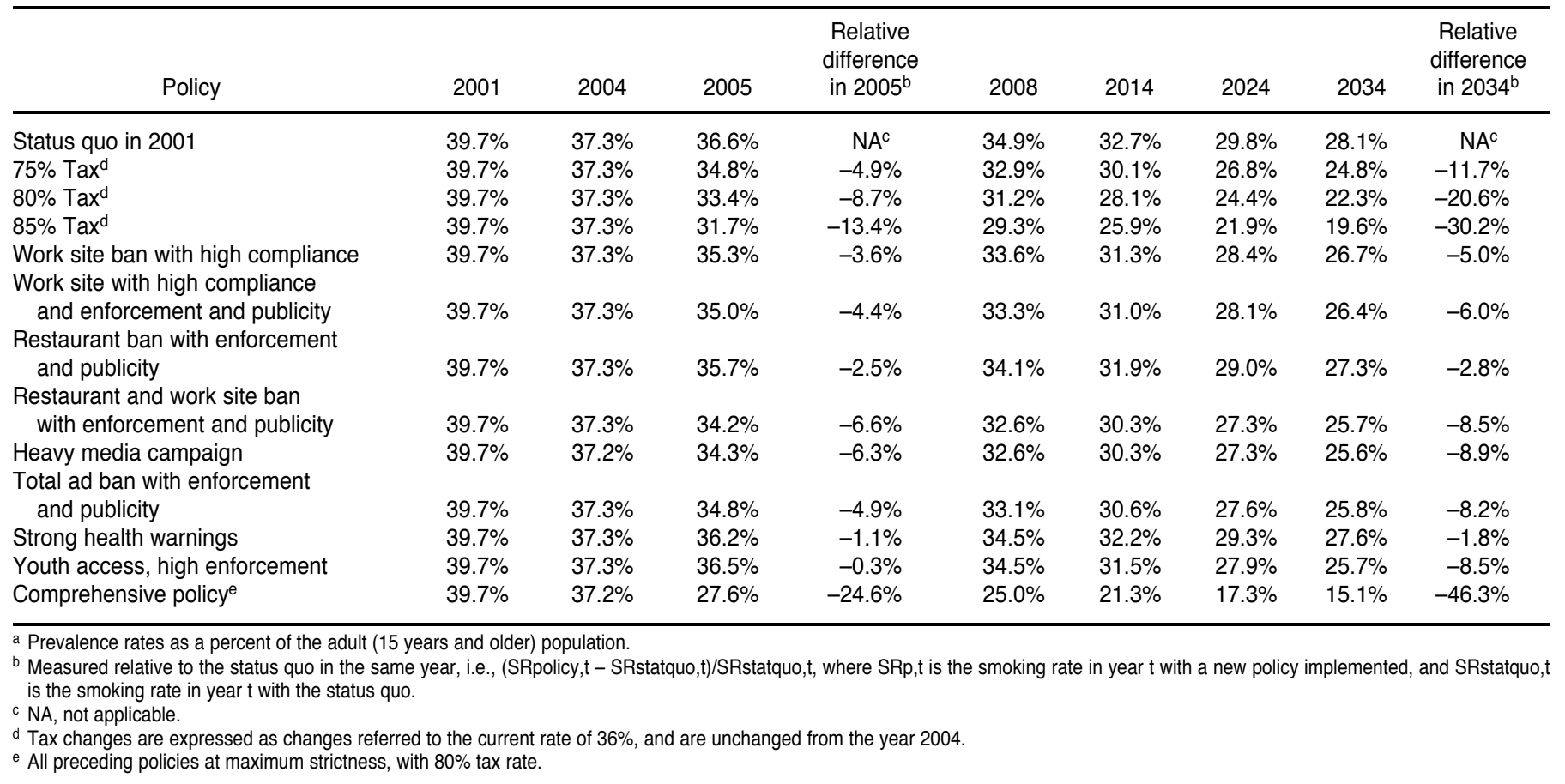

TABLE 3b. Smoking prevalence rates in females predicted for different years by the status quo model and under different scenarios of the Argentina Tobacco Policy Simulation Model ${ }^{a}$

\begin{tabular}{|c|c|c|c|c|c|c|c|c|c|}
\hline Policy & 2001 & 2004 & 2005 & $\begin{array}{l}\text { Relative } \\
\text { difference } \\
\text { in } 2005^{b}\end{array}$ & 2008 & 2014 & 2024 & 2034 & $\begin{array}{l}\text { Relative } \\
\text { difference } \\
\text { in } 2034^{b}\end{array}$ \\
\hline Status quo in 2001 & $26.9 \%$ & $25.5 \%$ & $25.1 \%$ & $\mathrm{NA}^{\mathrm{C}}$ & $24.2 \%$ & $22.8 \%$ & $21.0 \%$ & $19.8 \%$ & $\mathrm{NA}^{\mathrm{c}}$ \\
\hline $75 \% \operatorname{Tax}^{d}$ & $26.9 \%$ & $25.5 \%$ & $23.9 \%$ & $-4.8 \%$ & $22.8 \%$ & $21.1 \%$ & $18.9 \%$ & $17.6 \%$ & $-11.1 \%$ \\
\hline $80 \% \operatorname{Tax}^{d}$ & $26.9 \%$ & $25.5 \%$ & $22.9 \%$ & $-8.8 \%$ & $21.6 \%$ & $19.7 \%$ & $17.3 \%$ & $15.9 \%$ & $-19.7 \%$ \\
\hline $85 \% \operatorname{Tax}^{d}$ & $26.9 \%$ & $25.5 \%$ & $21.8 \%$ & $-13.1 \%$ & $20.4 \%$ & $18.2 \%$ & $15.6 \%$ & $14.1 \%$ & $-28.8 \%$ \\
\hline $\begin{array}{l}\text { Work site ban with high compliance } \\
\text { Work site with high compliance }\end{array}$ & $26.9 \%$ & $25.5 \%$ & $24.2 \%$ & $-3.6 \%$ & $23.2 \%$ & $21.9 \%$ & $20.0 \%$ & $18.9 \%$ & $-4.5 \%$ \\
\hline $\begin{array}{l}\text { and enforcement and publicity } \\
\text { Restaurant ban }\end{array}$ & $26.9 \%$ & $25.5 \%$ & $24.0 \%$ & $-4.4 \%$ & $23.0 \%$ & $21.6 \%$ & $19.7 \%$ & $18.6 \%$ & $-6.1 \%$ \\
\hline $\begin{array}{c}\text { with enforcement and publicity } \\
\text { Restaurant and work site ban with }\end{array}$ & $26.9 \%$ & $25.5 \%$ & $24.5 \%$ & $-2.4 \%$ & $23.6 \%$ & $22.2 \%$ & $20.4 \%$ & $19.3 \%$ & $-2.5 \%$ \\
\hline enforcement and publicity & $26.9 \%$ & $25.5 \%$ & $23.5 \%$ & $-6.4 \%$ & $22.5 \%$ & $21.1 \%$ & $19.2 \%$ & $18.2 \%$ & $-8.1 \%$ \\
\hline $\begin{array}{l}\text { Heavy media campaign } \\
\text { Total ad ban with enforcement }\end{array}$ & $26.9 \%$ & $25.4 \%$ & $23.5 \%$ & $-6.4 \%$ & $22.5 \%$ & $21.1 \%$ & $19.2 \%$ & $18.1 \%$ & $-8.6 \%$ \\
\hline and publicity & $26.9 \%$ & $25.5 \%$ & $23.8 \%$ & $-5.2 \%$ & $22.9 \%$ & $21.4 \%$ & $19.4 \%$ & $18.3 \%$ & $-7.6 \%$ \\
\hline Strong health warnings & $26.9 \%$ & $25.5 \%$ & $24.8 \%$ & $-1.2 \%$ & $23.9 \%$ & $22.5 \%$ & $20.6 \%$ & $19.5 \%$ & $-1.5 \%$ \\
\hline Youth access, high enforcement & $26.9 \%$ & $25.5 \%$ & $25.1 \%$ & $0.0 \%$ & $23.9 \%$ & $22.1 \%$ & $19.7 \%$ & $18.3 \%$ & $-7.8 \%$ \\
\hline Comprehensive policy ${ }^{e}$ & $26.9 \%$ & $25.4 \%$ & $18.9 \%$ & $-24.7 \%$ & $17.4 \%$ & $15.0 \%$ & $12.4 \%$ & $10.9 \%$ & $-44.9 \%$ \\
\hline
\end{tabular}

a Prevalence rates as a percent of the adult (15 years and older) population.

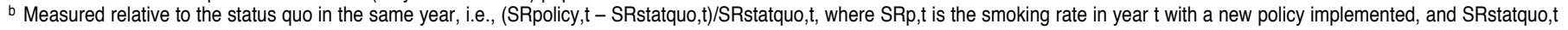
is the smoking rate in year $t$ with the status quo.

c NA, not applicable.

d Tax changes are expressed as changes referred to the current rate of 36\%, and are unchanged from the year 2004 .

If tobacco control policies remained unchanged from their 2004 levels (sta tus quo scenario), male smoking prevalence was predicted to decrease in rel- ative terms by $12.3 \%$ [(37.3-32.7)/37.3] in 10 years (2014), and by $20.1 \%$ after 30 years from its baseline level of $37.3 \%$, whereas smoking prevalence in female adults was predicted to decrease by $10.4 \%$ [(25.5-22.8)/25.5] in 10 years, and by $17.7 \%$ after 30 years from its baseline level of $25.5 \%$. Much of this 
TABLE 4a. Deaths in males attributable to smoking, predicted for different years by the status quo model and under different scenarios of the Argentina Tobacco Policy Simulation Model

\begin{tabular}{|c|c|c|c|c|c|c|c|c|c|}
\hline Policy & 2001 & 2004 & 2005 & 2008 & 2014 & 2024 & $\begin{array}{l}\text { Lives } \\
\text { saved in } \\
2024^{\mathrm{a}}\end{array}$ & 2034 & $\begin{array}{l}\text { Lives } \\
\text { saved in } \\
2034^{a}\end{array}$ \\
\hline $75 \% \operatorname{Tax}^{\mathrm{C}}$ & 44586 & 43682 & 43752 & 43607 & 44367 & 43416 & 1185 & 42515 & 1842 \\
\hline $80 \% \operatorname{Tax}^{\mathrm{C}}$ & 44586 & 43682 & 43752 & 43525 & 44119 & 42434 & 2168 & 41039 & 3318 \\
\hline $85 \% \operatorname{Tax}^{\mathrm{C}}$ & 44586 & 43682 & 43752 & 43427 & 43830 & 41308 & 3293 & 39404 & 4953 \\
\hline $\begin{array}{l}\text { Work site ban with high compliance } \\
\text { Work site with high compliance }\end{array}$ & 44586 & 43682 & 43752 & 43618 & 44355 & 43405 & 1197 & 42949 & 1408 \\
\hline $\begin{array}{l}\text { Restaurant ban with enforcement } \\
\text { and publicity }\end{array}$ & 44586 & 43682 & 43752 & 43621 & 44418 & 43800 & 801 & 43479 & 878 \\
\hline $\begin{array}{l}\text { Restaurant and work site ban } \\
\text { with enforcement and publicity }\end{array}$ & 44586 & 43682 & 43752 & 43521 & 44066 & 42422 & 2180 & 41872 & 2484 \\
\hline $\begin{array}{l}\text { Heavy media campaign } \\
\text { Total ad ban with enforcement }\end{array}$ & 44586 & 43682 & 43752 & 43472 & 43996 & 42427 & 2175 & 41942 & 2414 \\
\hline
\end{tabular}

a Calculated as the difference from the status quo figure for the same year.

b NA, not applicable.

c Tax changes are expressed as changes referred to the current rate of 36\%, and are assumed unchanged from the year 2004 .

${ }^{d}$ All preceding policies at maximum strictness, with $80 \%$ tax rate.

TABLE $4 \mathrm{~b}$. Deaths in females attributable to smoking, predicted for different years by the status quo model and under different scenarios of the Argentina Tobacco Policy Simulation Model

\begin{tabular}{|c|c|c|c|c|c|c|c|c|c|}
\hline Policy & 2001 & 2004 & 2005 & 2008 & 2014 & 2024 & $\begin{array}{c}\text { Lives } \\
\text { saved in } \\
2024^{a}\end{array}$ & 2034 & $\begin{array}{c}\text { Lives } \\
\text { saved in } \\
2034^{a}\end{array}$ \\
\hline Status quo in 2001 & 14326 & 15950 & 16498 & 17831 & 20502 & 24356 & $N A^{b}$ & 26645 & $N A^{b}$ \\
\hline $75 \% \operatorname{Tax}^{\mathrm{c}}$ & 14326 & 15950 & 16498 & 17776 & 20231 & 23641 & 714 & 25576 & 1069 \\
\hline $80 \% \operatorname{Tax}^{\mathrm{C}}$ & 14326 & 15950 & 16498 & 17728 & 20002 & 23047 & 1308 & 24711 & 1934 \\
\hline $85 \% \operatorname{Tax}^{\mathrm{C}}$ & 14326 & 15950 & 16498 & 17672 & 19733 & 22365 & 1990 & 23746 & 2898 \\
\hline $\begin{array}{l}\text { Work site ban with high compliance } \\
\text { Work site with high compliance }\end{array}$ & 14326 & 15950 & 16498 & 17781 & 20224 & 23621 & 735 & 25726 & 919 \\
\hline $\begin{array}{l}\text { and enforcement and publicity } \\
\text { Restaurant ban }\end{array}$ & 14326 & 15950 & 16498 & 17769 & 20161 & 23455 & 900 & 25521 & 1124 \\
\hline with enforcement and publicity & 14326 & 15950 & 16498 & 17783 & 20276 & 23835 & 521 & 26035 & 610 \\
\hline Restaurant and work site ban & & & & & & & & & \\
\hline with enforcement and publicity & 14326 & 15950 & 16498 & 17724 & 19955 & 22990 & 1366 & 24988 & 1656 \\
\hline $\begin{array}{l}\text { Heavy media campaign } \\
\text { Total ad ban with enforcement }\end{array}$ & 14326 & 15950 & 16498 & 17698 & 19881 & 22937 & 1418 & 24978 & 1667 \\
\hline and publicity & 14326 & 15950 & 16498 & 17726 & 20027 & 23296 & 1059 & 25407 & 1238 \\
\hline Strong health warnings & 14326 & 15950 & 16498 & 17809 & 20381 & 24049 & 306 & 26254 & 391 \\
\hline Youth access, high enforcement & 14326 & 15950 & 16498 & 17831 & 20502 & 24341 & 14 & 26492 & 153 \\
\hline Comprehensive policy ${ }^{d}$ & 14326 & 15950 & 16498 & 17390 & 18402 & 19375 & 4981 & 20459 & 6186 \\
\hline
\end{tabular}

a Calculated as the difference from the status quo figure for the same year.

${ }^{b}$ NA, not applicable.

c Tax changes are expressed as changes referred to the current rate of $36 \%$, and are assumed unchanged from the year 2004 .

${ }^{d}$ All preceding policies at maximum strictness, with $80 \%$ tax rate.

decline reflected deaths in older cohorts of smokers with higher smoking rates and replacement of these smokers by younger, more recent cohorts with slightly lower smoking rates.
As shown in Tables $4 \mathrm{a}$ and $4 \mathrm{~b}$, the estimated number of smoking-attributable deaths in 2004 was 43682 for males and 15950 for females. Compared to 2004, male deaths under the status quo scenario were projected to increase by 977 (44 659 - 43 682) over the 10-year period, and by 675 (44 357 43682 ) over the 30 -year horizon. Female deaths were projected to increase 
by 4552 over a 10 -year horizon, and by 10695 per year over a 30-year horizon. Thus, although smoking prevalence was projected to decrease slowly with time, deaths were projected to increase. The increases represented aging of cohorts with high smoking prevalence, especially among Argentine women.

Taxes. If taxes were increased from the current $68 \%$ to $75 \%$ of the retail price (leading to a $28 \%$ price increase), the ATPSM predicted that smoking prevalence would decrease by $4.7 \%$ in 2005 relative to the status quo scenario in the same year. By the end of the 30year projection period (the year 2034), male smoking prevalence was projected to decline by about $11.7 \%$ relative to the status quo. With an increase in taxes to $80 \%$ of the retail price, (leading to a price increase of $60 \%$ ), male smoking rates were predicted to decline by $8.7 \%$, and female smoking rates by $8.8 \%$, in the first year, and to decline by $20.6 \%$ for males and $19.7 \%$ for females after 30 years. With an increase in taxes to $85 \%$ of the retail price (a price increase of 113\%), male smoking rates were predicted to decline by $13.4 \%$, and female smoking rates by $13.1 \%$, in the first year, and by $30.2 \%$ for males and $28.8 \%$ for females after 30 years. Youth smoking prevalence was affected by taxes more than adult smoking prevalence in the model, so that taxes continued to reduce adult smoking rates with time as the young people who smoked at a reduced rate became adults.

The effect of taxes on deaths was delayed, because the effects of cessation were relatively slow to appear and the greatest effects of tax were on youth prevalence, which did not affect death rates for at least 20 years. Increasing the taxes to $75 \%$ of the retail prices slowed the increase in deaths compared to the status quo scenario, with 1899 lives saved per year (1 185 men, 714 women) by the year 2024, and 2911 lives saved per year (1 842 men, 1069 women) by the year 2034 . Increasing the tax to $85 \%$ of the retail price slowed the increase in deaths, with 7851 lives saved per year (4 953 men, 2898 women) by the year 2034 .

Clean air policies. A total work site smoking ban that was not well enforced and publicized was predicted to lead to a $3.6 \%$ reduction in male smoking prevalence in comparison to the status quo scenario after the policy was in effect for 1 year. With strong enforcement and public support, the effect was a larger short-term decrease of $4.4 \%$ in males. A policy with strong bans limited to restaurants and other public places yielded a long-term decrease of $2.5 \%$ in males. Moving to strong work site and restaurant bans with strong enforcement had the potential to reduce smoking rates by about $6.6 \%$. Slightly smaller effects were predicted for females, because of their lower labor participation rate. Comprehensive clean air laws, with both strong work site and restaurant bans and strong enforcement and publicity, were predicted to lead to about 2 484 fewer male and 1656 fewer female deaths per year by 2034 compared to the number of deaths under status quo assumptions.

Mass media and educational policies. We compared the effects of moderately and heavily publicized media campaigns directed at all smokers (i.e., not targeted to a specific population, such as youth) relative to the current policy of little publicity for the campaign. For a heavily publicized campaign implemented with other policies and sustained over time, the model predicted a $6.3 \%$ immediate reduction in smoking prevalence after 1 year for males and females, and this reduction increased to about an $8.9 \%$ with time. By 2034 , the decrease in projected annual deaths per year was 2414 males and 1667 females compared to the status quo scenario.

Advertising ban. Adding publicity and greater enforcement to a strict advertising ban was projected to yield a 4.9\% immediate reduction in the male smoking rate, and an $8.2 \%$ reduction by 2034 . The increased effect with time reflected the larger impact on youth smoking rates. This policy was projected to avoid 1836 male and 1238 female smoking-attributable deaths per year by the year 2034 .

Health warnings. Introducing strong health warnings rather than the current weak warnings was projected to yield a $1.1 \%$ immediate relative reduction in male smoking rates, and a relative reduction of about $1.8 \%$ by 2034 . Strong health warnings were projected to avoid 545 male and 391 female smoking-attributable deaths per year in 2034.

Youth access policies. With strict control of youth access and publicity, adult smoking rates declined imperceptibly after 1 year, because those under the age of 18 were a particularly small segment of the smoking population in Argentina. The effects were projected to increase to an $8.5 \%$ reduction for males and a $7.8 \%$ reduction for females by the year 2034. Because reductions in youth smoking rates did not affect death rates until age 36 , the annual number of smoking-attributable deaths did not decline much as a result of youth access policies. However, even with the small relative declines in adult prevalence, 364 male and 153 female deaths per year might be avoided by 2034 compared to the status quo scenario.

\section{Comprehensive set of policies}

The final scenario projected the effect of a combination of policies involving an increase to $80 \%$ tax on the retail price, comprehensive work site and restaurant smoking bans with enforcement and publicity, a highintensity media campaign, higher enforcement and publicity of the total ban on cigarette advertisements along with strong health warnings, and strict youth access controls. After the first year, smoking prevalence was projected to decrease about $24.6 \%$ in males and $24.7 \%$ in females in comparison to the status quo scenario. The smoking prevalence in 2034 was projected to decrease by more than $46.3 \%$ 
FIGURE 1. Male smoking rates in Argentina predicted by the status quo and the comprehensive strategy scenarios of the Argentina Tobacco Policy Simulation Model, 2001-2033

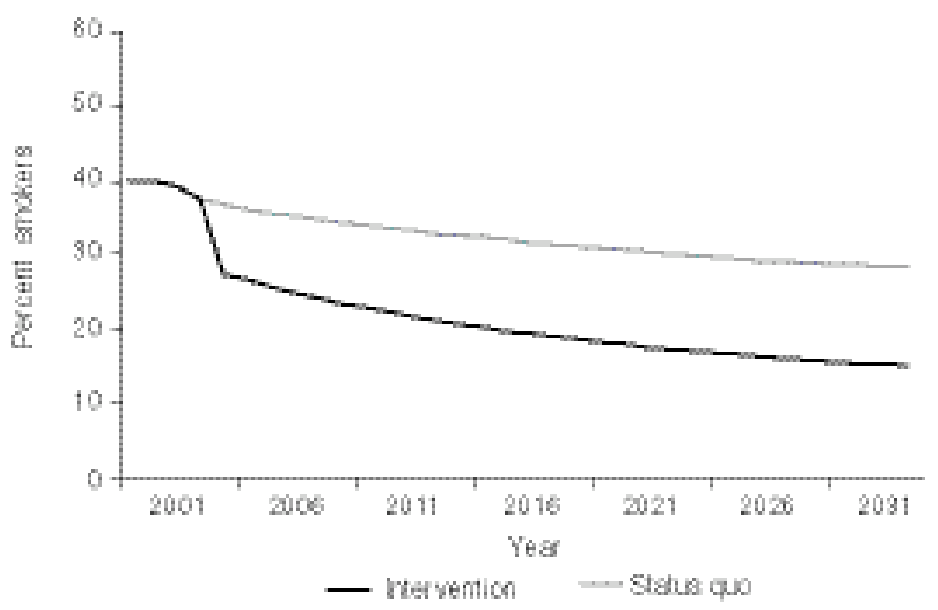

for males and $44.9 \%$ for females. The projected effects of a comprehensive policy on male smoking rates are shown in Figure 1.

Relative to status quo policies, 12762 (7871 male and 4981 female) fewer smoking-attributable deaths were predicted per year by 2024. By 2034, almost 16000 fewer deaths were predicted per year. If the number of lives saved per year is added up for all years, over 250000 lives would be saved by the year 2034, according to the model based on a comprehensive set of policies.

\section{DISCUSSION}

We used the ATPSM to obtain shortand long-term projections of the effect of various tobacco control policies on smoking prevalence and the number of deaths attributable to smoking. The largest effects resulted from a sizable increase in taxes. Although taxes are currently around $70 \%$ of the wholesale price of cigarettes, studies indicate that in Argentina the price of cigarettes is still low relative to the standard of living $(38,39)$. Improved mass media educational policies, advertising bans, and stricter clean air laws with enforcement and publicity could also have large immediate impacts.
Research has shown that the most effective tobacco control campaigns use a comprehensive set of policy measures (28), targeting different populations and filling different needs to reduce smoking prevalence and subsequent deaths. Our projections also indicate that with a comprehensive set of policies maintained over time, smoking prevalence would decrease substantially within 20 years.

Without effective tobacco control policies, there will be a substantial increase in the number of deaths due to smoking. Because of the natural progression of tobacco-related illnesses, early reductions in smoking prevalence have a relatively small impact on the number of smoking-attributable deaths in the short term, but the effect grows substantially with time. By 2034, the model predicted that almost 16000 lives might be saved in that year alone if the strongest policies were implemented. The projected $\mathrm{cu}-$ mulative effect of the comprehensive set of policies provides strong arguments for implementing a combination of policies as early as possible.

The ATPSM provided preliminary estimates of future smoking rates and deaths attributable to smoking, and showed how tobacco control policies might be expected to change those outcomes. The results, however, de- pend on the data, and on the assumptions and parameters underlying the population module, the smoking module, and each policy module.

The population module yielded data for different age groups and genders, but did not consider net immigration because this has been low in recent years. Fertility rates have also been low in recent years, but our population estimates are in line with those of other projections.

The smoking prevalence results from the smoking module depended on estimates of smoking rates, cessation, and initiation. The data for smoking rates were based on data from Argentina, where the definition of smoking has changed with time, and differed from the accepted definition of an established smokers (i.e., having smoked 100 or more cigarettes in a lifetime). Reliable data were not available for cessation and relapse rates, and were therefore based on United States rates. To improve the predictability of the model and to improve Argentina's surveillance system, it will be necessary to develop and collect consistent measures of prevalence, cessation and relapse rates for Argentina on an annual basis.

The results from the smoking module also depended on the assumption that initiation, cessation, and relapse 
were constant with time except as due to policy-induced changes. Our data indicated that smoking rates were noticeably lower in 2001 than in previous years, and it will be important to gauge youth smoking behaviors in $\mathrm{fu}-$ ture studies. In addition, the model produced smoking and death rates by gender, but assumed that the roles of sociodemographic groups were similar in both genders. As the population changes in future years with migration between different parts of the country, smoking and death rates may change.

The estimated relative death risks of smokers were based on data from the United States (1, 40, 41). However, the average quantity smoked per smoker was lower and the average duration of smoking may be shorter in Argentina than the United States (42). We also considered smoking-attributable deaths assuming relative risks of 1.6 for all ages, and the estimated number of smoking-attributable deaths in 2005 was 23909 for males and 6177 for females, which is 19847 fewer deaths for males and 10322 fewer deaths for females than with the higher United States relative risk. The difference compared to the United States relative risk decreased with time to 17687 for males and 10554 for females by 2034. Nevertheless, smoking intensity and duration have been rising in Argentina, as opposed to declining trends in the United States. Furthermore, the projections do not include deaths due to second-hand smoke exposure. In a recent survey (43), only 5\% of Argentines were free of exposure to second-hand smoke.
The policy modules depended on underlying assumptions, estimated parameters of the predicted effect on initiation and cessation, and assumptions about the interdependence of policies. Knowledge of the different effects of each policy varies (7). For example, many studies, with relatively consistent results, have examined the effects of price. There are also many studies of clean air laws; their results are somewhat less consistent than those of studies that examined prices and taxes, but still fall within certain ranges (44). Studies of media campaigns provide a broad range of estimates, and those on advertising bans are even less consistent. In addition, the policy parameters for the ATPSM were based primarily on studies in the United States, Australia and European nations. Although studies of price found similar and generally larger effects for countries with lower incomes, much less is known about the effects of other policies (28). In particular, studies need to be done for Argentina not only to gauge the initial effect of policies, but also to elucidate how policies unfold over time, and how their results depend on other policies in effect.

Finally, the model did not incorporate the effects of changes in income. As the economy improves and incomes rise, smoking rates might be expected to increase (42). Currently, there is little information on the role of income in Argentina. Given the lack of information, it is important to study how income affects tobacco consumption.
Given the limitations of the ATPSM and of simulation models in general, we designed the model so that it can be easily modified. We hope that the model will be used to encourage better data collection and additional research in Argentina. Evaluations of past policies and of future tobacco policies as changes are made merit particular attention. These evaluations can be used to modify and improve the predictive capacity of the ATPSM. With improved surveillance and evaluation, better information can be obtained about the effectiveness of tobacco control policies in Argentina, and the information can be used to improve existing tobacco control policies. In conjunction with the ATPSM, this information can also better inform policymakers of the effects of tobacco control policies on future smoking patterns and deaths attributable to smoking, so that policies can be modified as new information becomes available.

In conclusion, the ATPSM provides a tool that helps justify much-needed tobacco control policies in Argentina. As new policies are implemented, the model may become a planning tool. Other countries in Latin America have similar smoking rates, and will face the challenge of lowering these rates in future years. Models such as the one developed for Argentina should also be developed for other Latin American countries.

Acknowledgments. We would like to thank the Pan American Health Organization (PAHO) for the funding to develop the model.

\section{REFERENCES}

1. U.S. Department of Health and Human Services. Reducing the health consequences of smoking: 25 years of progress: a report of the Surgeon General. Atlanta: Centers for Disease Control and Prevention, National Center for Chronic Disease Prevention and Health Promotion, Office on Smoking and Health; 1989. (DHHS Publication No. [CDC] 89-8411).

2. U.S. Department of Health and Human Services. The health benefits of smoking cessation: a report of the Surgeon General. Atlanta: U.S. Department of Health and Human Services,
Public Health Service, Centers for Disease Control, Office on Smoking and Health.; 1990.

3. Ezzati M, Lopez AD. Estimates of global mortality attributable to smoking in 2000. Lancet 2003;362(9387):847-52.

4. Peto R, Lopez AD. Future worldwide health effects of current smoking patterns. In: Koop CE, CE P, Schwarz MR, editors. Critical issues in global health. San Francisco: Jossey-Bass; 2000. Pp. 154-61.

5. Hopkins DP, Briss PA, Ricard CJ, Husten CG, Carande-Kulis VG, Fielding JE, et al. Reviews of evidence regarding interventions to reduce tobacco use and exposure to environmental tobacco smoke. Am J Prev Med. 2001;20(2 Suppl):16-66.

6. U.S. Department of Health and Human Services. Healthy people 2010. Atlanta: Centers for Disease Control, Office of Disease Prevention and Health Promotion; 2000.

7. Levy DT, Gitchell JG, Chaloupka F. The effects of tobacco control policies on smoking rates: a tobacco control scorecard. J Public Health Manag Pract. 2004;10:338-51. 
8. Taylor DH, Jr., Hasselblad V, Henley SJ, Thun MJ, Sloan FA. Benefits of smoking cessation for longevity. Am J Public Health. 2002;92(6): 990-6.

9. World Health Organization. Updated status of the WHO Framework Convention on Tobacco Control. 2005. Available from: http:/ / www.who.int/tobacco/ framework/ country list/en/index.html. Accessed 24 Dec 2006.

10. Levy DT, Nikolayev N, Mumford EA. The Healthy People 2010 Smoking Prevalence and Tobacco Control Objectives: results from the SimSmoke Tobacco Control Policy Simulation Model. Cancer Causes Control. 2005;16(4): 359-71.

11. Levy DT, Nikolayev N, Mumford EA. Recent trends in smoking and the role of public policies: results from the SimSmoke Tobacco Control Policy Simulation Model. Addiction. 2005;10(10):1526-37.

12. Levy DT, Chaloupka F, Gitchell J, Mendez D, Warner KE. The use of simulation models for the surveillance, justification and understanding of tobacco control policies. Health Care Manag Sci. 2002;5(2):113-20.

13. Levy DT, Cummings KM, Hyland A. A simulation of the effects of youth initiation policies on overall cigarette use. Am J Public Health. 2000;90(8):1311-4.

14. McWhorter WP, Boyd GM, Mattson ME. Predictors of quitting smoking: the NHANES I followup experience. J Clin Epidemiol. 1990; 43(12):1399-405.

15. Gilpin EA, Pierce JP, Farkas AJ. Duration of smoking abstinence and success in quitting. J Natl Cancer Inst. 1997;89(8):572-6.

16. U.S. Centers for Disease Control. Cigarette smoking among adults-United States, 1998. Morb Mortal Wkly Rep. 2000;49(39):881-4.

17. Ciruzzi MA, Schargrosky H, Pramparo P, Rosloznik J, Zylbersztejn H, Haquim M, et al. Edad avanzanda y factores de riesgo para infarto agudo de miocardio. Medicina (Buenos Aires). 2002;62(6):535-43.

18. Ciruzzi M, Pramparo P, Rozlosnik J, Zylberstjn $\mathrm{H}$, Delmonte H, Haquim M, et al. Hypertension and the risk of acute myocardial infarction in Argentina. The Argentine Factores de Riesgo Coronario en America del Sur (FRICAS) Investigators. Prev Cardiol. 2001; 4(2):57-64.

19. Matos E, Vilensky M, Boffetta P, Kogevinas M. Lung cancer and smoking: a case-control study in Buenos Aires, Argentina. Lung Cancer. 1998;21(3):155-63.

20. Burns D, Garfinkel L, Samet J, eds. Changes in cigarette-related disease risks and their implication for prevention and control. Bethesda, MD: National Institutes of Health, National Cancer Institute; 1997.

21. U.S. Department of Health and Human Services. The health consequences of smoking.
Atlanta: Centers for Disease Control and Prevention, National Center for Chronic Disease Prevention and Health Promotion, Office on Smoking and Health; 2004.

22. Levy DT, Friend K, Polishchuk E. Effect of clean indoor air laws on smokers: the clean air module of the SimSmoke computer simulation model. Tob Control. 2001;10(4):345-51.

23. Levy DT, Friend K, Holder H, Carmona M. Effect of policies directed at youth access to smoking: results from the SimSmoke computer simulation model. Tob Control. 2001; 10(2):108-16.

24. Levy DT, Friend K. Examining the effects of tobacco treatment policies on smoking rates and smoking related deaths using the SimSmoke computer simulation model. Tob Control. 2002;11(1):47-54.

25. Levy DT, Friend K. A simulation model of policies directed at treating tobacco use and dependence. Med Decis Making. 2002;22(1): 6-17.

26. Levy DT, Friend K. A computer simulation model of mass media interventions directed at tobacco use. Prev. Med. 2001;32(3):284-94.

27. Levy DT, Cummings KM, Hyland A. Increasing taxes as a strategy to reduce cigarette use and deaths: results of a simulation model. Prev Med. 2000;31(3):279-86.

28. Chaloupka FJ, Hu T, Warner KE, Jacobs R, Yurekli A. The taxation of tobacco products. In: Jha P, Chaloupka F, eds. Tobacco control in developing countries. New York: Oxford University Press; 2000. Pp. 237-272.

29. Rozada MG, Sanchez G, Angueira M, Bartolomé Verra FJ. Analysis económico del consumo de tabaco en Argentina; 2002. Available from: http:/ / www.msal.gov.ar/htm/site tabaco/pdf/Estudio\%20econometrico\% 202002\%5B1\%5D\%5B1\%5D.final.pdf. Accessed 24 Dec 2006.

30. Farrelly M, Bray J. Responses to increases in cigarette prices by race/ethnicity, income, and age groups-United States, 1976-1993. Morb Mortal Wkly Rep. 1998;47(29):605-9.

31. Kenkel D, Chen L. Consumer information and tobacco use. In: Jha P, Chaloupka F, eds. Tobacco control in developing countries. New York: Oxford University Press; 2000. Pp. 177-214.

32. Levy DT, Mumford E, Pesin B. Tobacco control policies, and reductions in smoking rates and smoking-related deaths: results from the SimSmoke model. Expert Rev Pharmacoecon Outcomes Res. 2003;3(4):457-68.

33. Borland R. Tobacco health warnings and smoking related cognitions and behaviours. Addiction. 1997;92(11):1427-35.

34. Martens D. Graphic tobacco warnings having desired effect. Can Med Assoc J. 2002;166(11): 1453.
35. Hammond D, McDonald PW, Fong GT, Brown KS, Cameron R. The impact of cigarette warning labels and smoke-free bylaws on smoking cessation: evidence from former smokers. Can J Public Health. 2004;95(3): $201-4$.

36. Hammond D, Fong GT, McDonald PW, Cameron R, Brown KS. Impact of the graphic Canadian warning labels on adult smoking behaviour. Tob Control. 2003;12(4):391-5.

37. U.S. Centers for Disease Control. 2000 Global youth tobacco surveys. Available from: www. cdc.gov/tobacco/global/gyts/factsheets/ 2000/Argentina_factsheet.htm. Accessed 24 Dec 2006.

38. Blecher EH, van Walbeek CP. An international analysis of cigarette affordability. Tob Control. 2004;13(4):339-46.

39. Guindon GE, Tobin S, Yach D. Trends and affordability of cigarette prices: ample room for tax increases and related health gains. Tob Control. 2002;11(1):35-43.

40. Thun MJ, Myers DG, Day-Lally C, Namboodiri NM, Calle EE, Flanders WD, et al. Age and the exposure-response relationships between cigarette smoking and premature death in Cancer Prevention Study II. In: Burns D, Garfinkel L, Samet J, eds. Changes in cigarette related disease risks and their implication for prevention and control. Bethesda: National Cancer Institute; 1997. Pp. 383-475.

41. Burns D, Garfinkel L, Samet J, eds. Changes in cigarette-related disease risks and their implication for prevention and control. Bethesda: National Institutes of Health, National Cancer Institute; 1997.

42. U.S. Department of Health and Human Services. Smoking and health in the Americas: a report of the Surgeon General, in collaboration with the Pan American Health Organization. Atlanta: Centers for Disease Control and Prevention, National Center for Chronic Disease Prevention and Health Promotion, Office on Smoking and Health; 1992.

43. Argentina. Ministerio de Salud y Ambiente de la Nación. Encuesta de tabaquismo en grandes ciudades de Argentina, 2004. Programa Nacional de Control de Tabaco. Available from: http:/ / www.msal.gov.ar/htm/ site_tabaco/pdf/encuesta_tabaquismo.pdf. Accessed 24 Dec 2006.

44. Levy DT, Friend KB. The effects of clean indoor air laws: what do we know and what do we need to know? Health Educ Res. 2003; 18(5):592-609.

Manuscript received on 4 August 2005. Revised version accepted for publication on 1 November 2006. 
RESUMEN Objetivos. Se compararon las políticas de control del tabaco, independientemente y en su conjunto, mediante un modelo de simulación para proyectar la prevalencia de tabaquismo y la mortalidad prematura futura asociada con ese hábito en Argentina a partir de 2001.

El papel de las políticas en la reducción de la prevalencia de tabaquismo y de las muertes asociadas: el modelo de simulación de políticas antitabáquicas de Argentina

Palabras clave
Métodos. Se modificó un modelo de simulación de políticas de control del tabaco, conocido como SimSmoke, con los datos de población, fertilidad, mortalidad, prevalencia de tabaquismo y de las políticas de control del tabaco en efecto en Argentina entre 2001 y 2004. Se utilizó el modelo de simulación de políticas antitabáquicas de Argentina (MSPAA) para predecir el efecto sobre la prevalencia de tabaquismo que tendrían los cambios impositivos y de precios, las leyes de ambientes libres de humo, las campañas mediáticas y los programas para abandonar el hábito de fumar, y de las políticas de control del acceso de los jóvenes al tabaco sobre las tasas de inicio y abandono del tabaquismo. La prevalencia del hábito de fumar y los riesgos relativos de fumar se utilizaron para estimar la mortalidad atribuible al tabaquismo. Se empleó el MSPAA para proyectar la prevalencia de tabaquismo y las muertes atribuibles a este hábito durante el período 2001-2034.

Resultados. Las mayores reducciones en la prevalencia de tabaquismo y en la mortalidad prematura asociada con ese hábito se estimaron para un paquete de políticas integradas de control del tabaco, aunque se predijeron reducciones relativas de hasta $30 \%$ por grandes aumentos impositivos. La adición de campañas mediáticas junto a programas para difundir y aplicar las leyes de ambientes libres de humo, la prohibición de anuncios promocionales y las leyes que controlan el acceso de los jóvenes al tabaco podrían reducir las tasas de tabaquismo hasta en $45 \%$ para el año 2034 y salvarían casi 16000 vidas anualmente.

Conclusiones. Las políticas de control del tabaco pueden reducir considerablemente las tasas de tabaquismo, lo que podría salvar muchas vidas. Sin esas políticas, aumentarán el número de muertes por tabaquismo y los gastos médicos asociados. Se espera que el MSPAA brinde una guía para reducir las más importantes brechas informativas relacionadas tanto con la modelación como con la elaboración de políticas en Argentina, por ejemplo, la falta de datos sobre las tasas de inicio y abandono del tabaquismo y la necesidad de estudios sobre el efecto de las políticas. Se podrían desarrollar modelos similares para otros países latinoamericanos.

Modelos teóricos, simulación por computador, política de salud, tabaquismo, Argentina.

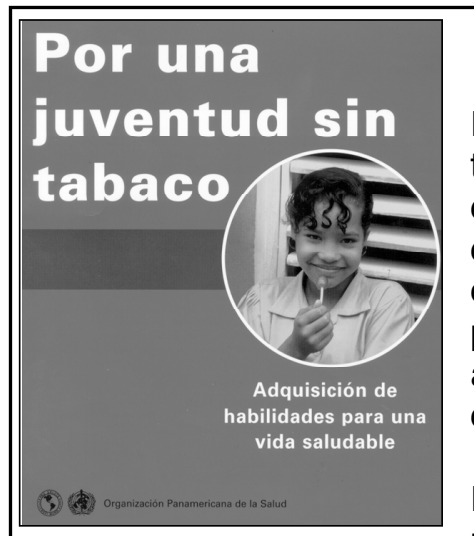

2001, 72p.,

ISBN 9275315795

Código: PC 579

Precios: US\$ 14.00 en América

Latina y el Caribe/

US\$ 18.00 en el resto del mundo

\section{Por una juventud sin tabaco}

En la primera parte del libro se muestran los problemas fundamentales del consumo de tabaco, especialmente para la juventud. Se revisan temas relacionados con la prevención de las enfermedades relacionadas con el tabaco en los países de la Región y se describen los aspectos más eficaces de los diferentes métodos usados para su prevención. En la segunda, se presentan los enfoques teóricos y prácticos del programa de prevención del hábito de fumar conocido como "Habilidades para la vida", que alecciona a los jóvenes para que sean capaces de resistir las presiones sociales y de los medios de comunicación que los incitan a fumar.

Esta publicación está destinada a los profesionales de la salud, los planificadores de programas, los educadores, los encargados de formular las políticas y los grupos e instituciones que participan en la lucha contra el tabaquismo.

Envíe su pedido y pago en dólares estadounidense a: http://publications.paho.org; correo electrónico: paho@pmds.com; Fax: (301) 209-9789; Tel: (301) 617-7806; (1-800) 472-3046 (U.S. solamente) 